\title{
DEVELOPMENT OF A METHOD FOR ANALYZING TOMOGRAPHIC IMAGES OF BONE STRUCTURES
}

The subject matter of research in the article is the morphological structure of bone tissue in the lumbar spine, visualized by tomography in the sagittal and axial planes. The goal of the research is to create the most informative investigation method for analyzing the structure of bone tissue, taking into account pathology in the form of metastatic bone lesions. This is justified by the fact that the detection of pathological processes is one of the most important tasks of image processing and analysis; at the same time, early diagnosis of various pathologies, including cancer, significantly increases the chances of patient recovery. Tasks: to consider the existing modern methods for analyzing the structure of bone tissue, to develop and propose a method for detecting bone tissue pathology in multiple myeloma. For the development of methods for the analysis of tomographic images with lesion of the bone structure, one of the fundamental issues is visualization of tomographic data. In this case, it is advisable to provide modules for both two-dimensional and three-dimensional visualization with methods of processing and segmentation of vertebral bodies, as well as correcting the results obtained in an interactive mode. The research uses methods of improving the quality of images, filtering using adaptive local filters, segmentation and stereology methods, cluster analysis method. The result of the work is to obtain a method suitable for use in the analysis of bone tissue with its accompanying pathology in the form of bone metastases. This method will be the basis for the further development of a method aimed at analyzing the microstructure of bone tissue, which will significantly increase the accuracy of calculations. Conclusions. The relevance of the topic under study is of vital importance for a huge number of patients suffering from cancer. In the course of the research, algorithms for processing and analyzing input images were developed, taking into account the modality of the input data. This makes it possible to develop the next stage of analysis aimed at the microstructure of the bone tissue.

Keywords: multiple myeloma; image processing; tumor; bone lesion; early diagnosis; image segmentation; bone structure; image filtering.

\section{Problem statement}

According to the Ministry of Health, there are more than 1 million cancer patients in Ukraine; 450 new cases of cancer are registered daily [1]. It should be noted that $90 \%$ of patients develop bone lesions during their disease. For this reason, imaging plays an important role in the diagnosis and follow-up of cancer patients. Bone pathology is the most common clinical feature of multiple myeloma (MM). Multiple myeloma is a tumor in the bone marrow that systemically affects the skeleton; characterized by clonal proliferation of plasma cells and bone marrow infiltration. Bone cancer metastases are characterized by bone marrow damage (diffuse, diffusefocal, rarely focal), accompanied by bone-destructive changes (osteoporosis, osteolysis), and the development of monoclonal immunoglobulinopathy [2-3].

Today, standard methods for examining bone tissue in MM determine bone mineral density, while some new methods focus on micro-objects. Terminologically, microobjects in the work are understood as objects on specially prepared micro-preparations. The variety of cellular and tissue structures found in the human body is considered to be medico-biological micro-objects [4]. In this work, the micro-object is taken as the trabecular structure of bone tissue and elements of its morphological structure.

The quality of image analysis and further development of research methods directly depend on the quality of the obtained diagnostic images - first of all, these are the results of X-ray computed tomography (CT) and radionuclide imaging [5]. At the same time, the lack of an integrative approach to assessing the morphofunctional parameters of bone structures makes it difficult and hinders the detection of pathological processes at early stages.

\section{Analysis of recent research and publications}

Recent advances in imaging make it possible to assess bone microstructure in vivo using high-resolution peripheral quantitative computed tomography [5-6].

Imaging techniques used to assess the structure of the trabecular bone include conventional $\mathrm{x}$-rays, magnification X-rays, high-resolution computed tomography (HRCT), and high-resolution MRI (MRIHR).

High-resolution MRI (HR-MRI) techniques can provide three-dimensional information about cancellous bone in peripheral regions with a resolution of the order of trabecular dimensions (in-plane resolution: $110 \mu \mathrm{m}$, section thickness: $300 \mu \mathrm{m}$ ) [7-10]. Recent advances also allow imaging of the proximal femur, a major area of clinical interest, although the signal-to-noise ratio (SNR) and resolution (in-plane resolution: $\sim 250 \mu \mathrm{m}$, slice thickness: $\sim 500 \mu \mathrm{m}$ ) are lower than peripheral areas [11].

MRI scans can also be used to generate 3D bone geometry for finite element analysis (FEA) models. It is a numerical method that can be used to predict the mechanical response of a bone to stress. [12].

The scanning electron microscopy method allows us to estimate the pore size, shape and direction of trabeculae, identify their destruction, and evaluate the structure of bone collagen [13].

The method of peripheral quantitative CT (HRpQCT) is also known, which is used for visualization of bone microstructure, but its spatial resolution is 200-500 microns [14].

The method of optical microscopy is based on histological preparations of trabecular bone tissue with post-traumatic changes in structure, studied under an optical microscope. Morphometric changes are 
characterized by a decrease in the area of bone beams and a violation of the integrity of bone lacunae [13-15].

The method of multi-detector CT is widely used in clinical practice. However, the resolution of this method is $0.5-1 \mathrm{~mm}$, while the dimensions of the bone trabecula are $0.25-0.7 \mathrm{~mm}$ and the distance between them is $0.1-1.0 \mathrm{~mm}$ [16].

\section{Highlighting previously unsolved parts of a common problem. Purpose of work}

Analysis of the literature showed that despite the variety of methods, there is no suitable method for assessing the bone structure with high sensitivity. It should also be noted that a specific and especially important task in the work is not only the analysis of the structure of bone tissue at the micro level, but a combination of this issue with pathological changes associated with the complexity of the course of oncological diseases.

Thus, due to the heterogeneous structure of the bone structure and the random location of metastatic lesions in them, the analysis of tomographic images is complicated. In this regard, the task of developing new methods for analyzing bone structures remains relevant.

\section{Materials and methods}

The material of the research is tomographic images of sections of the vertebrae L1-L5 (fig. 1).

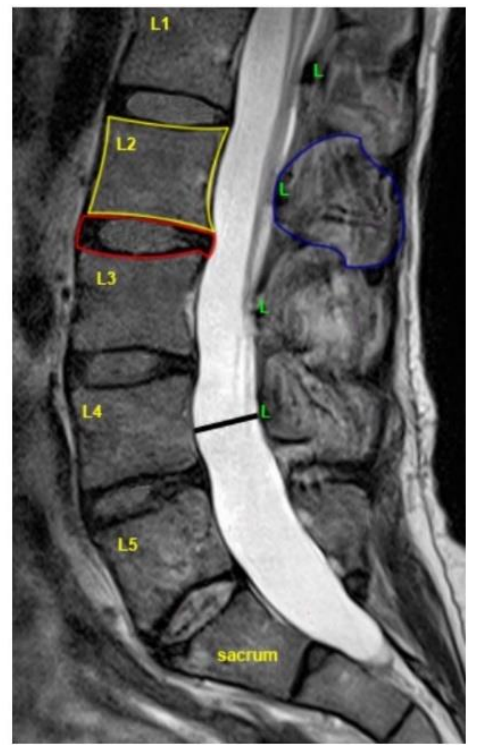

Fig. 1. MRI of the spine with selected areas of interest (vertebra L1-L5); sagittal T2-weighted MRI, middle section of the lumbar region

In the development of a tomographic image analysis system for multiple myeloma, one of the fundamental issues is the visual presentation of tomographic data. Therefore, for the purpose of expediency, twodimensional visualization modules are provided.

Two-dimensional processing involves working with images of individual tomographic slices and includes various types of brightness-contrast correction, methods of linear and nonlinear filtering of images, adjusted in accordance with user settings. Data processing, in addition to improving the visual perception of images, should provide the possibility of performing the segmentation procedure - highlighting areas in the image that belong to structures with common properties, which are chosen for tomographic images: intensity, configuration, size and localization.

According to the standard technique, magnetic resonance imaging (MRI) is performed in the sagittal and axial planes of the T2-weighted type, if necessary, supplemented by T1-weighted MRI in different planes, as well as MRI with fat suppression.

At the first stage, the image is analyzed from the point of view of subjective perception. The image has a normal distribution of the brightness of the elements and for the convenience of further calculations the normal distribution criterion is applied. The image quality is assessed by the degree of deviation of the real brightness distribution from the normal one. In addition to a quantitative assessment, this method allows you to obtain information about the presence and weight ratio of the brightness gradations of the image.

These transformations are carried out according to the expression (1):

$$
L_{\text {res }}=\frac{L-L_{\min }}{L_{\max }-L_{\min }},
$$

where $L, L_{r e s}-$ an array of values, respectively, of the original and resulting images; $L_{\min }, L_{\max }$ - respectively, the minimum and maximum values of the original image.

Transformations according to formula (1) are effective if the intensities of the pixels of potentially information areas are concentrated in a narrow dynamic range. If we apply these transformations to the original image, then we will not achieve the desired effect, since the histograms of its color components occupy the entire possible range.

Improving the visual quality of the original image can be achieved by modifying expression (1), i.e. to make stretching of dynamic range of intensities of image pixels nonlinear:

$$
L_{r e s}=\left(\frac{L-L_{\min }}{L_{\max }-L_{\min }}\right)^{\alpha},
$$

where $\alpha$-nonlinearity coefficient.

Further, at the second stage, due to the specific properties of tomographic images, filtration is applied using adaptive local filters (3). Mathematically, this filtration can be expressed as follows:

$$
g(x, y)=f(x, y)-\frac{\delta_{\eta}^{2}}{\delta_{L}^{2}}\left[f(x, y)-m_{L}\right],
$$

where $g(x, y)$ - filtered image in general; $f(x, y)$ initial image; $\delta_{L}^{2}-$ local variance in the $S_{x y}$, 
neighborhood, $S_{x y}-$ rectangular neighborhood with dimensions $\mathrm{m} \times \mathrm{n}$ in the point $(x, y) ; \delta_{\eta}^{2}-$ overall image noise variance; $m_{L}$ - local mean in the $S_{x y}$ neighborhood

At the third stage, you need to perform segmentation. We can use the $k$-means method. This method is one of the simplest and most common clustering methods if you know the number of classes to split data into. You can use this algorithm to segment medical images.

The $k$-means clustering algorithm is as follows:

a) $N$ classes are created ( $N$ is the number of classes into which the data should be split). The centers of mass of the classes are initialized to a specific value. Can be initialized with random values; b) the data that needs to be clustered are sequentially analyzed and belong to the class to which they are closest (according to the Euclidean distance and the center of mass);

c) the center of mass is recalculated for each class;

d) if in some class the center of mass is changed, then there is a transition to step "b";

e) based on the smallest distance of the center of mass of the cluster and the corresponding data, the data is assigned to a certain class.

Applying this method to the samples under study, we obtain the following results: fig. 2a shows an axial section of an MRI vertebra in normal conditions, and fig. $2 b$ shows the result of its segmentation using the $k$-means method.

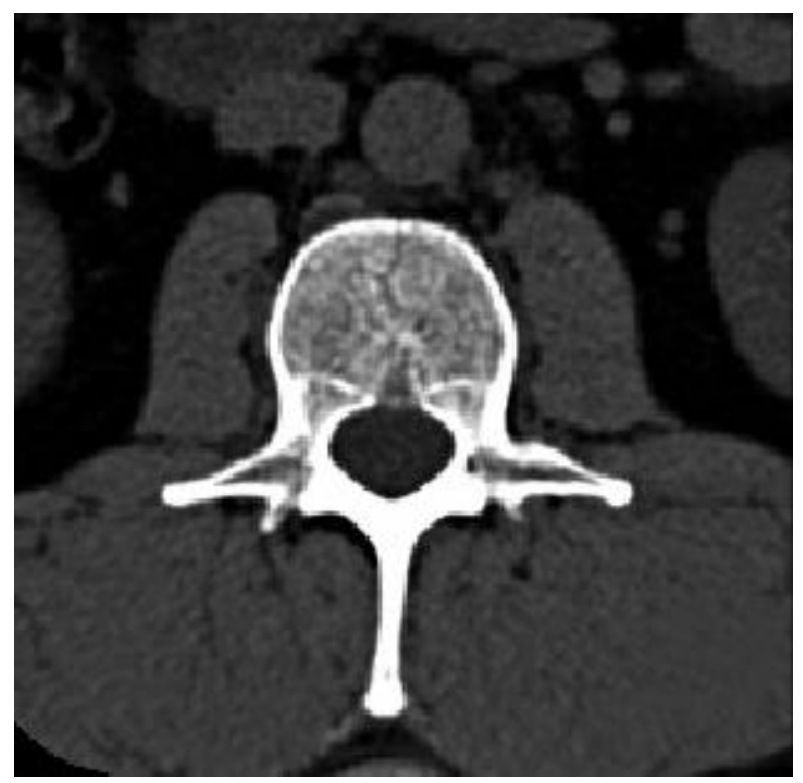

Fig. 2a. Computed tomogram of the lumbar spine, axial section, norm

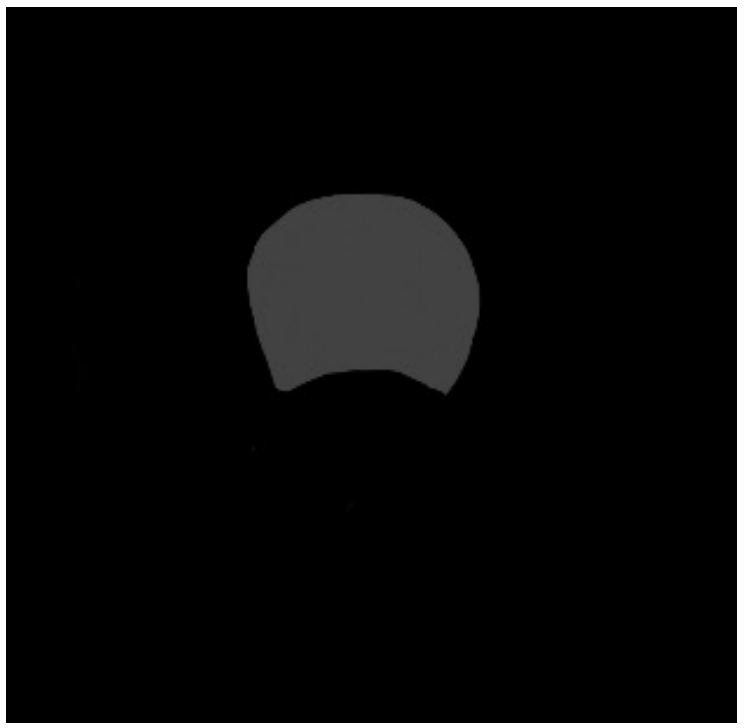

Fig. 2b. Result of fig. 2a segmentation by k-means method

As a result of segmentation, the region of interest shown in fig. $2 b$ was obtained; this region covers the entire area of the bone marrow in the vertebra. The image is ready for the next stages of processing.
Next, we will carry out the same analysis for the sample with pathology shown in fig. 3a. The segmentation result in fig. $3 b$. 


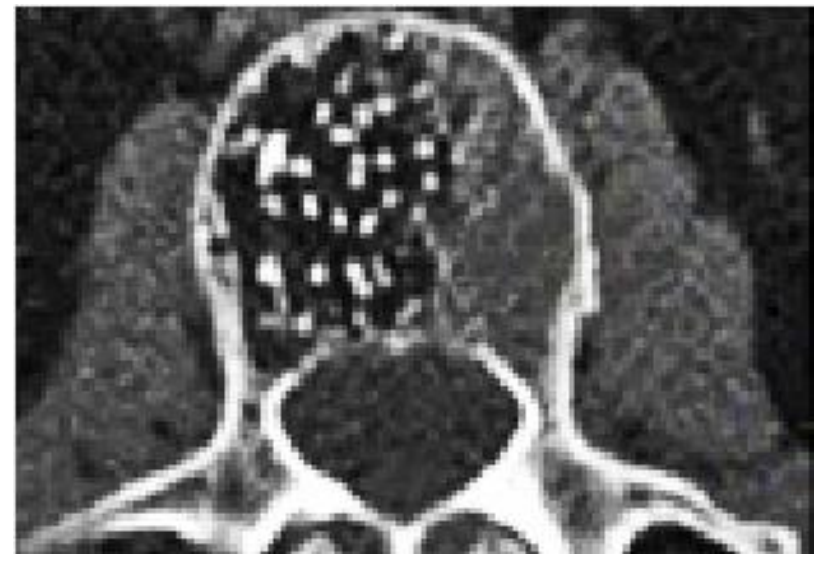

Fig. 3a. Computed tomogram of the lumbar spine, axial section, pathology

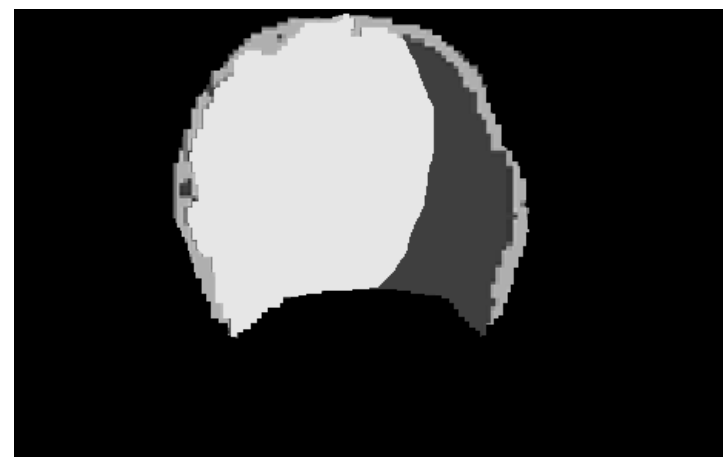

Fig. 3b. The result of segmentation of fig. 3a by the k-means method

On the tomogram shown in fig. 3a, the area with tissue structure disturbance is on the left. This condition is explained by the presence of bone metastasis, which destroys the trabecular structure of the spine. Fig. $3 b$ shows the result of image segmentation $3 \mathrm{a}$; the white segment is an area with a lesion that should be looked at during image analysis.

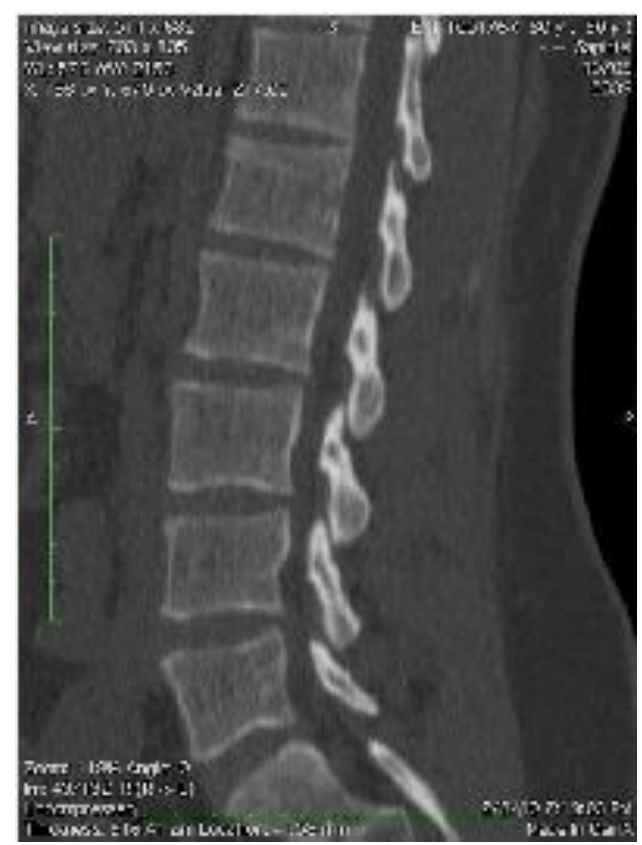

Fig. 4a. CT scan of the lumbosacral region, norm
Since this study considers the principle of analyzing images obtained by both MRI and computed tomography, we present the results of segmentation of images of the lumbosacral spine obtained in both methods to illustrate the modality.

Fig. 4a shows a CT scan of the lumbosacral spine, normal. Fig. $4 \mathrm{~b}$ shows the result of segmentation of this image by the k-means method.

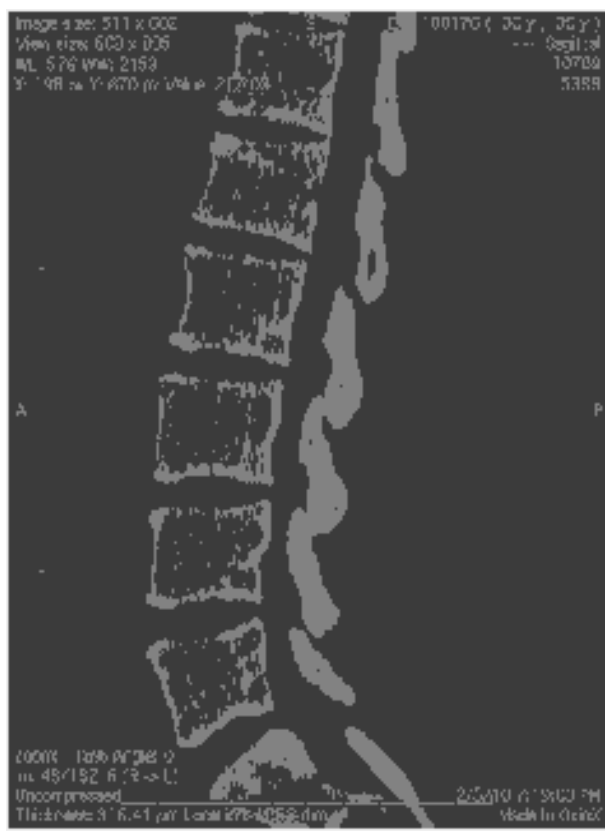

Fig. 4b. The result of segmentation of fig. 4a by the k-means method 
For visual comparison, fig. 5a shows such an image, only obtained as a result of MRI. Fig. 5b shows, respectively, the result of its segmentation by the k-means method.

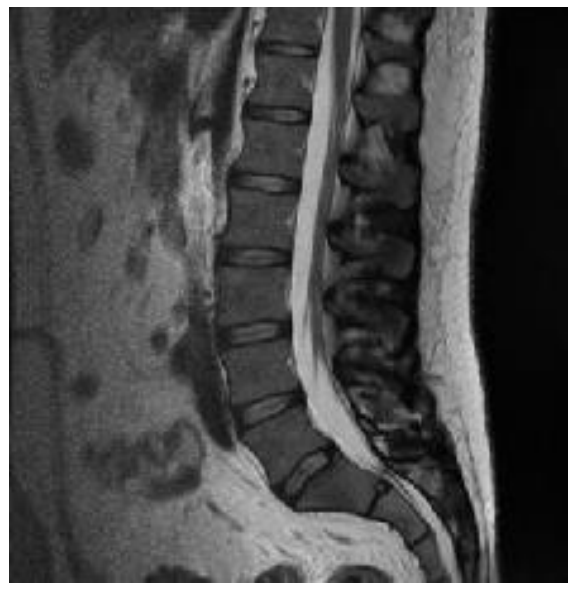

Fig.5a. MRI of the lumbosacral region, norm

Both imaging techniques, MRI and CT, have a very wide range of applications and are very popular. It is not entirely correct to compare these diagnostic methods, since they are based on different technological processes and use different approaches for tissue visualization. CT and MRI have their own advantages and disadvantages. The feasibility of using a particular technique is determined by the doctor, based on the goals and objectives of the study.

After the above steps have been completed, the image is ready for the next, fourth step, which consists in working directly with the areas of interest. In this work, the object for research is the affected vertebral bodies.

Cancer metastases in bone are characterized by damage to the bone tissue by cancer cells, which penetrate into it with the flow of blood and lymph from the primary tumor. In addition, these cancer cells can spread to other organs and tissues, forming metastases in them.

The main cells of bone tissue are osteoblasts, which are responsible for the formation of new cells and bone growth, and osteoclasts, which are responsible for the destruction and absorption of used bone cells.

When the bones are affected by metastases, the functions of the above cells are disrupted, and therefore, bone metastases, depending on the type of lesion, are divided into:

- osteolytic: when osteoclasts are damaged, bone thinning occurs, leading to pathological fractures under stress. With the progression of the disease, these signs may appear even with the slightest exertion (for example, when getting out of bed, when trying to take a step, etc.);

- osteoblastic: when osteoblasts are damaged, a pathological increase in bone tissue, the formation of growths and protrusions on the bone, limitation of joint mobility are diagnosed;

- mixed: damage to osteoblasts and osteoclasts. They are found most often in patients with bone metastases and are manifested by bone thinning and the appearance of new metastases.

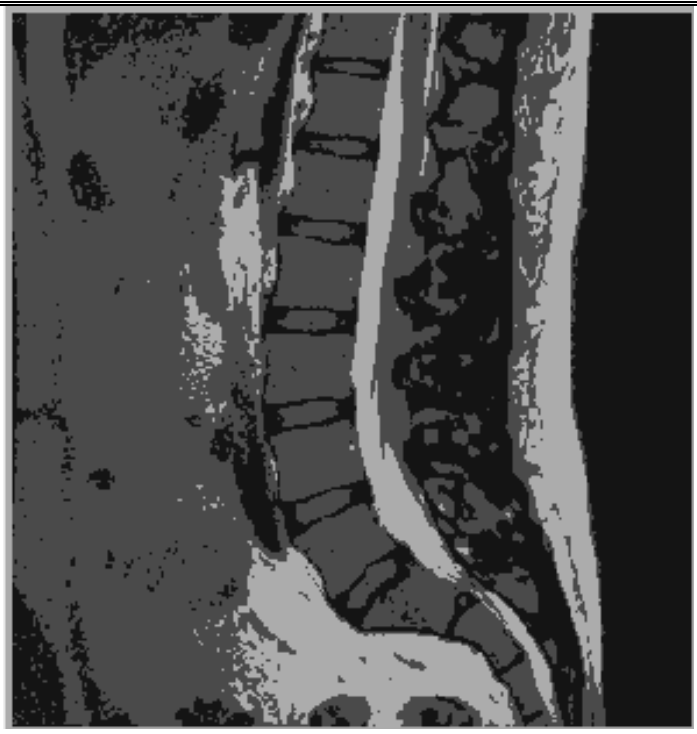

Fig. 5b. The result of segmentation of fig. 5a by the k-means method

Radiographically, they appear as small foci of vacuum or larger foci of destruction with a homogeneous or cellular structure. The edges of the lesions are usually indistinct, without a sclerotic ring of the seal.

After completing the above steps, the image is ready for the main processing module. The main fifth stage is as follows: in the image without pathology, an area is highlighted so that the object of interest is located inside it. The selection area corresponds to the size of the vertebral body. A maximum intensity graph is then plotted over this area. Further, to compare the results, it is necessary to carry out the same steps for a sample with pathology. After that, for each of the cases, the area of the integral curve is calculated. With pathology, the area will be smaller. For further interpretation of the value of the area difference and the development of the algorithm, a coefficient characterizing the area defect is introduced. With the help of the value of this coefficient, it is possible to distribute patients according to the degree of complexity of the disease, and as a result, help the radiologist to select an individual treatment and further monitor the dynamics.

\section{Research results and their discussion}

The result of the work is the development of a method suitable for use in the analysis of bone tissue in pathology in the form of bone metastases. However, this method will also be useful in the further follow-up of the patient and response to therapy. It should also be noted that the results obtained in this study will be the basis for the further development of a method aimed at analyzing the microstructure of bone tissue, which will increase the accuracy of calculations.

\section{Conclusions and prospects for further development}

The relevance of the topic under study is of vital importance for a huge number of patients suffering from cancer. During the study, a method was developed for 
processing and analyzing tomographic images, namely, bone structures, in the form of vertebrae, in patients with multiple myeloma. The obtained result makes it possible to develop the next analysis module aimed at the microstructure of bone tissue.
The results obtained are planned to be used in the future to describe the state of the vertebrae with pathologies and disorders. In the future, the development of an analysis method aimed at the microstructure of trabecular bone tissue, taking into account the presence of pathology.

\section{References}

1. "Center for Medical Statistics of the Ministry of Health of Ukraine" : website, available at :http://medstat.gov.ua/ukr/main.html (last accessed 1.02.2020).

2. Avrunin, O., Abramova, A. (2019), "The main signs of bone lesions in multiple myeloma", Science and technology: zb. scientific works DVNZ "PDTU", Mariupol, No. 20, P. 174-181.

3. Bäuerle, T., Hillengass, J., Fechtner, K. et al. (2009), "Multiple myeloma and monoclonal gammopathy of undetermined significance: importance of whole-body versus spinal MR imaging", Radiology, No. 2 (252), P. 477-485.

4. Proskurina, M., Stegachev, S., Yudin, A. (2012), "Metastatic lesion of the vertebral body", Medical imaging, No. 2, P. $129-130$.

5. Avrunin, O. (2009), "Experience in the development of a biomedical system of digital microscopy", Applied radio electronics, No. 1 (8), P. 46-52.

6. Kang, D. J., Lee, S. J., Na, J. E., Seong, M. J., Yoon, S. Y., Jeong, Y. W., Ahn, J. P., Rhyu, I. J. (2018), "Atmospheric scanning electron microscopy and its applications for biological specimens", Microscopy Research and Technique, Vol. 82, No. 1, P. 53-60.

7. Kim, G. J., Yoo, H. S., Lee, K. J., Choi, J. W., Hee, A. J. (2018), "Image of the micro-computed tomography and atomic-force microscopy of bone in osteoporosis animal model", Journal of Nanoscience and Nanotechnology, Vol. 18, No. 10, P. 6726-6731.

8. Avrunin, O. (2006), "Experience in software development for tomographic data visualization", Bulletin of NTU "KhPI", No. 23, P. 3-8.

9. Choël, L., Last, D., Duboeuf, F., Seurin, M. J., Lissac, M., Briguet, A., Guillot, G., Choel, L., Last, D., Duboeuf, F., Seurin, M. J., Lissac, M., Briguet, A., Guillot, G. (2004), "Trabecular alveolar bone microarchitecture in the human mandible using high resolution magnetic resonance imaging", Dentomaxillofacial Radiol, No. 33 (3), P. 177-182.

10. Krug, R., Burghardt, A. J., Majumdar, S., Link, T. M. (2010), "High-Resolution Imaging Techniques for the Assessment of Osteoporosis", Radiol. Clin. North Am., No. 48 (3), P. 601-621.

11. Chang, G., Deniz, C. M., Honig, S., Egol, K., Regatte, R. R., Zhu, Y., Sodickson, D. K., Brown, R. (2014), "MRI of the hip at 7T: feasibility of bone microarchitecture, high-resolution cartilage, and clinical imaging", Magn. Reson. Imaging, No. 39 (6), P. 1384 1393.

12. Magland, J. F., Rajapakse, C. S., Wright, A. C., Acciavatti, R., Wehrli, F. W. (2010), "3D fast spin echo with out-of-slab cancellation: a technique for high-resolution structural imaging of trabecular bone at 7 Tesla", Magn. Reson. Med., No. 63 (3), P. 719 727.

13. Wegst, U. G. K., Bai, H., Saiz, E., Tomsia, A. P., Ritchie, R. O. (2015), "Bioinspired structural materials", Nature Materials, Vol. 14, P. 23-36.

14. Koga, D., Kusumi, S., Shodo, R., Dan, Y., Ushiki, T. (2015), "High-resolution imaging by scanning electron microscopy of semithin sections in correlation with light microscopy", Microscopy, Vol. 64, No. 6, P. 387-394.

15. Koga, D., Ushiki, T., Watanabe, T. (2017), "Novel scanning electron microscopy ethods for analyzing the 3D structure of the Golgi apparatus", Anatomical Science International, Vol. 92, No. 1, P. 37-49.

16. Han, S. W., Tamaki, T., Adachi, T. (2015), "A novel osteoblast/osteocyte selection method in primary isolated chick bone cells by atomic force microscopy", Journal of Nanoscience and Nanotechnology, Vol. 15, No. 5, P. 3923-3927.

Received 26.08.2020

\section{Відомості про авторів / Сведения об авторах / About the Authors}

Абрамова Ганна Арнольдівна - Харківський національний університет радіоелектроніки, аспірант кафедри біомедичної інженерії, Харків, Україна; email: hanna.abramova@nure.ua; ORCID: http://orcid.org/0000-0002-8911-8202.

Абрамова Анна Арнольдовна - Харьковский национальный университет радиоэлектроники, аспирант кафедры биомедицинской инженерии, Харьков, Украина.

Abramova Hanna - Kharkiv National University of Radio Electronics, Postgraduate Student of the Department of Biomedical Engineering, Kharkiv, Ukraine.

Аврунін Олег Григорович - доктор технічних наук, професор, Харківський національний університет радіоелектроніки, завідувач кафедри біомедичної інженерії, Харків, Україна; email: oleh.avrunin@nure.ua; ORCID: http://orcid.org/0000-0002-6312-687X.

Аврунин Олег Григорьевич - доктор технических наук, профессор, Харьковский национальный университет радиоэлектроники, заведующий кафедры биомедицинской инженерии, Харьков, Украина.

Avrunin Oleg - Doctor of Sciences (Engineering), Professor, Kharkiv National University of Radio Electronics, Head of the Department of Biomedical Engineering, Kharkiv, Ukraine.

\section{РОЗРОБКА МЕТОДУ АНАЛІЗУ ТОМОГРАФІЧНИХ ЗОБРАЖЕНЬ КІСТКОВИХ СТРУКТУР}

Предметом дослідження в статті є морфологічна структура кісткової тканини у поперековому відділі хребта, візуалізована томографією в сагітальній і аксіальній площинах. Метою роботи є створення найбільш інформативного методу дослідження 
аналізу структури кісткової тканини з урахуванням патології у вигляді метастатичного ураження кісток. Це обумовлено тим, що виявлення патологічних процесів є однією з найважливіших задач обробки та аналізу зображень; при цьому рання діагностика різних патологій, включаючи рак, значно збільшує шанси відновлення пацієнтів Завдання: розглянути існуючі сучасні методи аналізу структури кісткової тканини, розробити і запропонувати метод виявлення патології кісткової тканини при множинній мієломі. Для розробки методів аналізу томографічних зображень при ураженні кісткової структури одним 3 основоположних питань $є$ наочна візуалізація томографічних даних. При цьому доцільно передбачити модулі як двомірної, так і тримірної візуалізації з методами обробки і сегментації тіл хребців, а також корекції отриманих результатів в інтерактивному режимі. В роботі використовуються методи підвищення якості зображень, фільтрації із застосуванням адаптивних локальних фільтрів, методи сегментації і стереологіi, метод кластерного аналізу. Результатом роботи $\epsilon$ отримання методу, придатного для використання в аналізі кісткової тканини з супутньою патологією у вигляді кісткових метастазів. Даний метод буде основою для подальшої розробки методу, спрямованого на аналіз мікроструктури кісткової тканини, що в рази збільшить точність розрахунків. Висновки. Актуальність досліджуваної теми має життєво важливе значення для величезної кількості пацієнтів, які страждають на онкозахворювання. У процесі дослідження було розроблено алгоритми обробки і аналізу вхідних зображень з урахуванням модальності вхідних даних. Це дає можливість розробляти наступний етап аналізу, спрямований на мікроструктуру кісткової тканини.

Ключові слова: множинна мієлома; обробка зображень; пухлина; ураження кісток; рання діагностика; сегментація зображень; структура кістки; фільтрація зображень.

\section{РАЗРАБОТКА МЕТОДА АНАЛИЗА ТОМОГРАФИЧЕСКИХ ИЗОБРАЖЕНИЙ КОСТНЫХ СТРУКТУР}

Предметом исследования в статье является морфологическая структура костной ткани в поясничном отделе позвоночника, визуализированная томографией в сагиттальной и аксиальной плоскостях. Целью работы является создание наиболее информативного метода исследования для анализа структуры костной ткани с учетом патологии в виде метастатического поражения костей. Это обосновано тем, что обнаружение патологических процессов является одной из важнейших задач обработки и анализа изображений; при этом ранняя диагностика различных патологий, включая рак, значительно увеличивает шансы восстановления пациентов Задачи: рассмотреть существующие современные методы анализа структуры костной ткани, разработать и предложить метод выявления патологии костной ткани при множественной миеломе. Для разработки методов анализа томографических изображений при поражении костной структуры одним из основополагающих вопросов является наглядная визуализация томографических данных. При этом целесообразно предусмотреть модули как двухмерной, так и трехмерной визуализации с методами обработки и сегментации тел позвонков, а также коррекции получаемых результатов в интерактивном режиме. В работе используются методы повышения качества изображений, фильтрации с применением адаптивных локальных фильтров, методы сегментации и стереологии, метод кластерного анализа. Результатом работы является получение метода, пригодного для использования в анализе костной ткани с сопутствующей ее патологией в виде костных метастазов. Данный метод будет основой для дальнейшей разработки метода, направленного на анализ микроструктуры костной ткани, что в разы увеличит точность расчетов. Выводы. Актуальность исследуемой темы имеет жизненно важное значение для огромного количества пациентов, страдающих онкозаболеваниями. В процессе исследования были разработаны алгоритмы обработки и анализа входных изображений с учетом модальности входных данных. Это дает возможность разрабатывать следующий этап анализа, направленный на микроструктуру костной ткани.

Ключевые слова: множественная миелома; обработка изображений; опухоль; поражение костей; ранняя диагностика; сегментация изображений; структура кости; фильтрация изображений.

\section{Бібліографічні описи / Bibliographic descriptions}

Абрамова Г. А., Аврунін О. Г. Розробка методу аналізу томографічних зображень кісткових структур. Сучасний стан $\begin{array}{llllll}\text { наукових досліджень та технологій в промисловості. } 2020 . & \text { № } 3 \text { (13). } & \text { C. } 115-121 .\end{array}$ DOI: https://doi.org/10.30837/ITSSI.2020.13.115.

Abramova, H., Avrunin, O. (2020), "Development of a method for analyzing tomographic images of bone structures", Innovative Technologies and Scientific Solutions for Industries, No.3(13), P. 115-121. DOI: https://doi.org/10.30837/ITSSI.2020.13.115. 